\title{
Application of magnetic correlation analysis on the choice and correction of cutting parameters for automated manufacturing systems
}

Prof. Eng. Karel Kocman, D.Sc.

Institute of Production Engineering, Faculty of Technology Tomas Bata University in Zlin

The paper is focused on the optimization of cutting parameters and their correction using magnetic correlation kinetic analysis to determine the workability of the material machined. The integrity of the surface layers, dimension and shape accuracy and cost of production is primarily dependent on the input parameters of the cutting process with particular workpiece material and its workability, the required quality, working conditions, type of cutting tool, workpiece material and machine tool. Different homogeneity causing uneven machinability, its early detection and quantitative assessment before entering into the semi-machining process is an important factor to stabilize and optimize the cutting process, especially in automated manufacturing. The identification of variations in machinability of the desired state can use the principle magnetic correlation analysis of the material and the values used to control and optimize the cutting process. This principle can be applied to adaptive control of modal commands direct change in the control program.

Keywords: Magnetic correlation analysis, optimization, theory of cutting, cutting tools, kinetic machinability

\section{References}

[1] AB SANDVIK, Sandviken, Sveden. Understanding Cemented Carbide - Grain size. [online]. Dostupné na Word Wide http://www.hardmaterials.sandviken.com

[2] DeGARMO,E.-BLACK,T.-KOSHER,R. : Materials and Processes in Manufacturing. Edit. Horton Marcia, London, S.1259, 1997

[3] HOLEŠOVSKÝ,F., NOVÁK,M., MICHNA Š.: Studium změn broušené povrchové vrstvy při dynamickém zatěžování. In Strojírenská technologie, FVTM Ústí n. Labem, 2007, str. 73 - 77, ISSN 1211-4162

[4] KOCMAN,K.-HRUŠKA,K.: Autorské osvědčení ČSSR č.245114. Vysoké učení technické v Brně, 20.4.1984 Způsob zjišt’ování obrobitelnosti feromagnetických materiálů a zařízení k provádění tohoto způsobu.

[5] KOCMAN, K.: Využití nedestruktivních metod k predikci kinetické obrobitelnosti s aplikací na optimalizaci a korekci řezných parametrů pro NC stroje a AVS. [Doktorská práce], VUT - FS Brno.

[6] KOCMAN, K.: Technologické procesy obrábění. CERM s.r.o. Brno, leden 2011, 330 s., ISBN 978-80-7204-722-2

[7] Kocman,K. - Lukovics,I.: Thermal surface effect when precise grinding polymeric parts. Mezinárodní vedecká konference "Fukčni povrchy 2006", Trenčín, 14-15. června 2006, s. 114 - 120, ISSN 1336-9199.

[8] KOCMAN, K. - PROKOP, J.: Determinant of kinetic machinability and corrections of cuttingparameters for numerically controlled machine tool. In: Mezinárodní vědecká konference, TU Košice,1996 